\title{
Self Assembled Rotaxane and Pseudo-Rotaxanes based on $\beta$-Cyclodextrin Inclusion Compounds with trans-1,4-Bis[(4-pyridyl)ethenyl]benzene-pentacyanoferrate(II) Complexes
}

\author{
Sergio H. Toma and Henrique E. Toma*
}

\author{
Instituto de Química, Universidade de São Paulo, CP 26077, 05513-970 São Paulo-SP, Brazil
}

\begin{abstract}
Os compostos de inclusão de trans-1,4-bis[(4-piridil)etenil]benzeno (BPEB) e os correspondentes complexos de pentacianoferrato(II) com $\beta$-ciclodextrina foram estudados em solução aquosa por espectroscopia ${ }^{1} \mathrm{H}$ RMN e UV-Visível. Compostos de inclusão com estequiometria 1:1 foram encontrados para todos os sistemas em solução. Na presença de $\beta$-ciclodextrina, o complexo binuclear de ferro $\left.\left\{\left[\mathrm{Fe}(\mathrm{CN})_{5}\right]_{2}(\mathrm{BPEB})\right]\right\}^{6-}$ é convertido espontaneamente em rotaxanos contendo os grupos $\left[\mathrm{Fe}(\mathrm{CN})_{5}\right]^{3-}$ como grupos terminais volumosos, por um mecanismo de automontagem dissociativa, confirmado por espectroscopia de ${ }^{1} \mathrm{H}$ RMN.
\end{abstract}

Inclusion compounds of trans-1,4-bis[(4-pyridyl)ethenyl]benzene (BPEB) and their corresponding pentacyanoferrate(II) complexes with $\beta$-cyclodextrin have been studied in aqueous solution by ${ }^{1} \mathrm{H}$ NMR and UV-Visible spectroscopy. All the inclusion compounds exhibit 1:1 stoichiometry is aqueous solution. In the presence of $\beta$-cyclodextrin, the binuclear $\left\{\left[\mathrm{Fe}(\mathrm{CN})_{5}\right]_{2}(\mathrm{BPEB})\right]^{6-}$ complex is gradually converted into rotaxane species bearing $\left[\mathrm{Fe}(\mathrm{CN})_{5}\right]^{3-}$ end groups, by a self assembly inclusion mechanism, as confirmed by ${ }^{1} \mathrm{H}$ NMR spectroscopy.

Keywords: cyclodextrins, inclusion complexes, rotaxanes, NMR

\section{Introduction}

Self-assembled organization has been a subject of great relevance in supramolecular chemistry and nanotechnology, ${ }^{1}$ and may be achieved by means of the association of molecular entities promoted by electrostatic forces, hydrogen bonding or van der Waals forces. This can be illustrated by the rotaxanes and pseudo-rotaxanes inclusion compounds in which a cyclic molecule encloses a rod-like molecule by non-covalent forces, having in addition, suitable end groups to prevent dethreading. Among the cyclic species, the cyclodextrins (CDs) provide an important class of molecules comprising six $(\alpha-C D)$, seven $(\beta-C D)$, or eight $(\gamma-C D) D-$ (+)-glucopyranose units linked through $\alpha-1,4$ glycosidic bonds, in a torus shape (Figure 1). ${ }^{2}$ Their ability to include guest molecules arises from the hydrophobic internal environment, suitable for accommodating aromatic molecules, ${ }^{3-5}$ water insoluble drugs, ${ }^{6-8}$ and inorganic compounds. ${ }^{9-15}$ Such inclusion compounds result from the energetically unfavorable interaction between the included water molecules in the hydrophobic CD cavity on one hand,

*e-mail: henetoma@iq.usp.br and between water and guest on the other, in comparison with the hydrophobic and/or van der Waals interactions between the guest and the host cavity.

Because of its $\pi$-conjugated planar shape \{trans1,4-bis[(4-pyridyl)ethenyl]benzene , here denoted BPEB, its corresponding pentacyanoferrate(II)
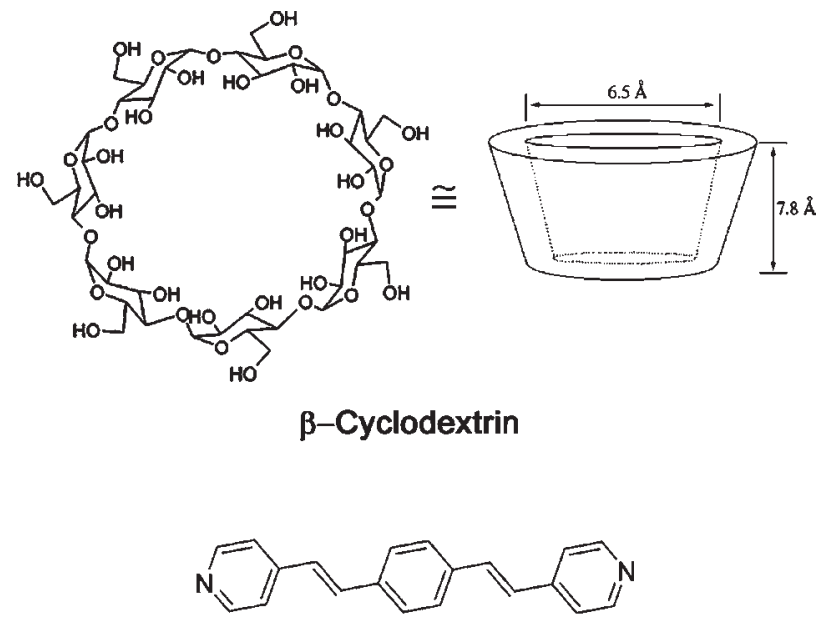

BPEB

Figure 1. Structural representation of B-CD host and BPEB guest ligand. 
complex, $\left\{\left[\mathrm{Fe}(\mathrm{CN})_{5}\right]_{2} \mathrm{BPEB}\right\}^{6-}$, provide suitable guest molecules for interacting with $\beta-C D$, yielding inclusion compounds of rotaxane or pseudo-rotaxane type. The supramolecular aspects involved in this system were investigated by means of UV-Visible and NMR spectroscopy, and the results are reported in this paper.

\section{Experimental}

All solvents and reactants were of analytical grade and employed without further purification. $\beta$-Cyclodextrin was purchased from Aldrich and dried at $80^{\circ} \mathrm{C}$ under vacuum for at least 12 hours before use. $\mathrm{Na}_{3}\left[\mathrm{Fe}(\mathrm{CN})_{5} \mathrm{NH}_{3}\right] \cdot 3 \mathrm{H}_{2} \mathrm{O}$, employed as a source of $\left[\mathrm{Fe}(\mathrm{CN})_{5}\right]^{3-}$ ions, was prepared from $\mathrm{Na}_{2}\left[\mathrm{Fe}(\mathrm{CN})_{5} \mathrm{NO}\right] .2 \mathrm{H}_{2} \mathrm{O}$, as previously described..$^{16}$ trans $-1,4-$ bis[2-(4-Pyridyl)ethenyl]-benzene was prepared by the Heck $\operatorname{method}^{17,18}$ and purified by recrystallization from a hot ethanol-water mixture. Anal. Found: C, 83.4; H, 5.8; N, 9.7\%. Required for $\mathrm{C}_{20} \mathrm{H}_{16} \mathrm{~N}_{2}\left(\mathrm{MW}=284.36 \mathrm{~g} \mathrm{~mol}^{-1}\right.$ ): $\mathrm{C}, 84.5 ; \mathrm{H}$, 5.7; N, 9.6\%. Observed $[\mathrm{M}+\mathrm{H}]^{+}: \mathrm{m} / \mathrm{z}$ 285.12. The dimeric iron complex, $\left.\left\{\left[\mathrm{Fe}(\mathrm{CN})_{5}\right]_{2} \mathrm{BPEB}\right]\right\}^{6-}$, was generated in aqueous solution, by the addition of 2 equivalents of the $\left[\mathrm{Fe}(\mathrm{CN})_{5}\right]^{3-}$ ion to 1 equivalent of the BPEB.

NMR spectra were recorded on an INOVA-1 $300 \mathrm{MHz}$ spectrometer, using TMS as the external chemical shift reference. All measurements were carried out in $\mathrm{D}_{2} \mathrm{O}$ solution with concentrations ranging from $1-10 \times 10^{-3} \mathrm{~mol}$ $\mathrm{dm}^{-3}$. For the NMR experiments involving BPEB, DCl ( $\mathrm{pD} \sim 3$ ) was added to the solution in order to improve its solubility. The UV-visible spectra were recorded on a Hewlett Packard model 8453 diode array spectrophotometer using $\sim 10^{-5} \mathrm{~mol} \mathrm{dm}^{-3}$ metal complexes solutions. For the binding constants measurements, the temperature and ionic strength were kept at $25.0 \pm 0.1^{\circ} \mathrm{C}$ and $0.1 \mathrm{~mol}$ $\mathrm{dm}^{-3} \mathrm{NaCl}$, respectively. The stoichiometry of $\beta-\mathrm{CD}$ inclusion compound with the BPEB ligand and with their metal complexes were obtained by means of the Continuous Variation Method (Job's method). ${ }^{19,20}$ In this method the total concentration of the species $\left([\mathrm{S}]_{0}+[\mathrm{L}]_{0}\right.$ $=\mathrm{M})$ is kept constant, and the ratio $\left(\mathrm{r}=[\mathrm{S}]_{0} /\left\{[\mathrm{S}]_{0}+\right.\right.$ $\left.[\mathrm{L}]_{0}\right\}$ ) between the S (BPEB) and $\mathrm{L}(\beta-\mathrm{CD})$ species is varied from 0 to 1 . The maximum complex concentration is reached for $r=(n+1)^{-1}$ and does not depend on the concentration $\mathrm{M}$ or the binding constant $\left(\mathrm{K}_{\mathrm{a}}\right)$.

The inclusion constant $\left(\mathrm{K}_{\mathrm{a}}\right)$ for the $\left[\left(\mathrm{FeCN}_{5}\right)_{2}(\right.$ BPEB. $\beta$ $\mathrm{CD})]^{6-}$ complex was determined from direct spectrophotometric measurements at $\lambda=420 \mathrm{~nm}$, using a large excess of $\beta-C D$ (e.g. ten fold excess). The temperature and ionic strength were kept constant at $25.0 \pm 0.1^{\circ} \mathrm{C}$ and $0.1 \mathrm{~mol} \mathrm{dm}^{-3} \mathrm{NaCl}$. In the determination of $\mathrm{K}_{\mathrm{a}}$ we assumed the following equilibrium,
$\mathrm{S}+\mathrm{L} \rightleftharpoons \mathrm{SL}$

where the $\left[\left(\mathrm{FeCN}_{5}\right)_{2} \mathrm{BPEB}\right]^{6-}$ complex, $\beta$-CD and $\left[\left(\mathrm{FeCN}_{5}\right)_{2}\right.$ (BPEB. $\beta-C D)]^{6-}$ refer to the substrate (S), ligand (L) and the inclusion complex (SL), respectively. The absorbance of the substrate in the presence of $\mathrm{CD}$ is given by:

$A=\varepsilon_{S} b[S]+\varepsilon_{L} b[L]+\varepsilon_{S L} b[S L]$

Making use of mass balance for the ligand and substrate:

$\mathrm{A}=\varepsilon_{\mathrm{L}} \mathrm{b}[\mathrm{L}]_{\mathrm{o}}+\Delta \varepsilon_{\mathrm{SL}} \mathrm{b}[\mathrm{SL}]$

where $\Delta \varepsilon_{\mathrm{SL}}=\varepsilon_{\mathrm{SL}}-\varepsilon_{\mathrm{S}}-\varepsilon_{\mathrm{L}}$. Combining equation 2 with $\mathrm{K}_{\mathrm{a}}$ definition and after rearranging:

$\frac{\Delta \mathrm{A}}{\mathrm{b}}=\frac{\Delta \varepsilon_{\mathrm{SL}} \mathrm{K}_{\mathrm{a}}[\mathrm{S}][\mathrm{L}]_{\mathrm{o}}}{1+\mathrm{K}_{\mathrm{a}}[\mathrm{S}]}$

Equation 3 describes the absorption changes for a 1:1 complexation process. Several related methods can also be proposed. For instance, in the Scatchard ${ }^{21}$ method, equation 3 becomes

$\frac{\Delta \mathrm{A}}{\mathrm{b}[\mathrm{S}]}=-\frac{\Delta \mathrm{AK} \mathrm{K}_{\mathrm{a}}}{\mathrm{b}}+\Delta \varepsilon_{\mathrm{SL}} \mathrm{K}_{\mathrm{a}}[\mathrm{L}]_{\mathrm{o}}$

By plotting $\Delta \mathrm{A} / \mathrm{b}[\mathrm{S}]$ against $-\Delta \mathrm{A} / \mathrm{b}$, the slope is given by $\mathrm{K}_{\mathrm{a}}$ and $\Delta \varepsilon_{\mathrm{SL}}$ can be obtained by extrapolation to infinite dilution.

Alternatively, for the NMR evaluation of the binding constant $(\mathrm{Ka})$, the area of peaks of the $\mathrm{H}_{\alpha}$ protons of the free complex $\left[\left(\mathrm{FeCN}_{5}\right)_{2} \mathrm{BPEB}\right]^{6-}$ and the rotaxane $\left[(\mathrm{FeCN})_{5}\right)_{2}($ BPEB. $\left.\beta-\mathrm{CD})\right]^{6-}$ species can be directly employed in the calculations.

\section{Results and Discussion}

\section{Determination of the stoichiometry}

The BPEB inclusion was characterized in $\mathrm{D}_{2} \mathrm{O} / \mathrm{DCl}$ by ${ }^{1} \mathrm{H}$ NMR spectroscopy. In Figure 2 (a-e) are shown the ${ }^{1} \mathrm{H}$ spectra of the aromatic BPEB guest $(\mathrm{a}-\mathrm{c})$ and the $\beta$-CD host (d-e) in different molar ratios. The characteristic BPEB chemical shifts were collected in Table 1, for comparison purposes.

In this system, a fast exchange regime between the included and non-included forms was observed in the NMR time-scale. The non-splitting of the $\alpha, \beta, \gamma$ and $-\mathrm{CH}=\mathrm{CH}-$ guest protons signals, and the shift of the resonance 
frequency as function of the $\mathrm{BPEB} / \beta-\mathrm{CD}$ molar ratio can be interpreted in terms of a fast exchange between the free and included species. The downfield shifts of the BPEB aromatic protons are in agreement with the change of the polar solvent environment by the more hydrophobic $\beta-C D$ cavity. Upfield shifts of the $\mathrm{H}_{3}$ and $\mathrm{H}_{5} \beta-\mathrm{CD}$ protons were observed in the $\beta$-CD spectra. Upon inclusion, the $\mathrm{H}_{3}$ and $\mathrm{H}_{5}$ protons lay over the aromatic BPEB ligand. Thus the circulating electrons generate a magnetic field inducing a diamagnetic moment opposed to the external field. Consequently, the anisotropic effect over the inner protons of the $\beta-C D$ cavity is negative, producing a shielding effect.

In order to determine the inclusion stoichiometry of the $\mathrm{BPEB} / \beta-\mathrm{CD}$ system, the continuous variation method was employed (Figure $2 \mathrm{~g}-\mathrm{h}$ ). As discussed before, ${ }^{22}$ this method makes use of the difference in the chemical shifts $\left(\Delta \delta=\delta_{0}-\delta\right)$ of the ligand (or substrate) in a fast chemical exchange regime at constant total concentration. In this sense, the chemical shift observed for a given nucleus can be expressed as function of the mole fraction of the species L and SL, e.g.,

$\delta_{0}=\mathrm{f}_{\mathrm{L}} \delta_{\mathrm{L}}+\mathrm{f}_{\mathrm{SL}} \delta_{\mathrm{SL}}$

where $\mathrm{f}_{\mathrm{L}}=[\mathrm{L}] /[\mathrm{L}]_{0}$ and $\mathrm{f}_{\mathrm{SL}}=[\mathrm{SL}] /[\mathrm{L}]_{0} ; \delta_{\mathrm{L}}$ and $\delta_{\mathrm{SL}}$ are the chemical shifts of the $\beta-\mathrm{CD}(\mathrm{L})$ and the $(\mathrm{BPEB} \times \beta-$ $\mathrm{CD}$ ) inclusion complex (SL), respectively. Thus, the experimentally observed parameter (e.g. the chemical shift of the ligand) is sensitive to the complex formation. Plotting $\Delta \delta_{x}[\mathrm{~L}]$ versus the mole fraction of the ligand (r), the maximum is reached at $\mathrm{n}=0.5$ indicating $1: 1$ stoichiometry.

\section{Self-assembly of $\left\{\left[\mathrm{Fe}(\mathrm{CN})_{5}\right]_{2}(\mathrm{BPEB} \cdot \beta-\mathrm{CD})\right\}^{6-}$ rotaxanes}

The presence of the two $\left[\mathrm{Fe}(\mathrm{CN})_{5}\right]^{3-}$ moieties attached to the BPEB ligand was expected to prevent the inclusion of the complex into $\beta-\mathrm{CD}$, in contrast to the free BPEB species. As a matter of fact, the linear bridged $\left\{\left[\mathrm{Fe}(\mathrm{CN})_{5}\right]_{2}(\mathrm{BPEB})\right\}^{6-}$ complex was observed to interact relatively slowly with $\beta-C D$ in $\mathrm{D}_{2} \mathrm{O}$ or aqueous solutions, at a time scale comparable with that for ligand substitution reactions in pentacyanoferrate(II) complexes. Such slow changes allowed the monitoration of the reaction by ${ }^{1} \mathrm{H}$ NMR spectroscopy (Figure 3).

Before examining the ${ }^{1} \mathrm{H}$ NMR changes, it should be noted (Table 1) that in the starting $\left\{\left[\mathrm{Fe}(\mathrm{CN})_{5}\right]_{2}(\mathrm{BPEB})\right\}^{6-}$ complex, the $\alpha(2)$ and $\beta(3)$ signals are downfield and upfield shifted with respect to the BPEB free ligand, respectively. This behavior is well understood for pentacyanoferrate(II) complexes bearing pyridyl ligands. ${ }^{23,24}$ The $\alpha$ (2) hydrogen downfield shifts is caused by the paramagnetic anisotropy of the Fe(II) core and influenced by electric field effects arising from the dipole moments of the triple-bond cyano ligand. Interestingly, the $\beta$ (3) proton is shifted upfield from its resonance position in the free ligand. The chemical shift mechanism is based on change in the charge density over the pyridyl moiety of the BPEB ligand by the shielding caused by $\mathrm{d} \pi \rightarrow \mathrm{p} \pi$ back-bonding from the pentacyanoferrate(II) complex.

The addition of $\beta-C D$ to the dimer solution results on the gradual NMR changes shown in Figure 3(b-e). The inclusion effect causes a breakage of symmetry of the complex, splitting of the protons resonance signals. Unlike the $\mathrm{BPEB} / \beta-\mathrm{CD}$ fast regime, the pentacyanoferrate(II) groups prevent the rapid exchange of the included complex. The estimated life time for the formation of the rotaxane species based on the ${ }^{1} \mathrm{H}$ NMR signals was about 5 min. A similar decay time was observed by treating the $\left\{\left[\mathrm{Fe}\left(\mathrm{CN}_{5}\right)\right]_{2}(\mathrm{BPEB})\right\}^{6-}$ complex with excess of dimethyl sulfoxide (DMSO), which is a well known strong complexing agent for pentacyanoferrate(II) ions $\left(\mathrm{k}_{\mathrm{d}}=7.5\right.$

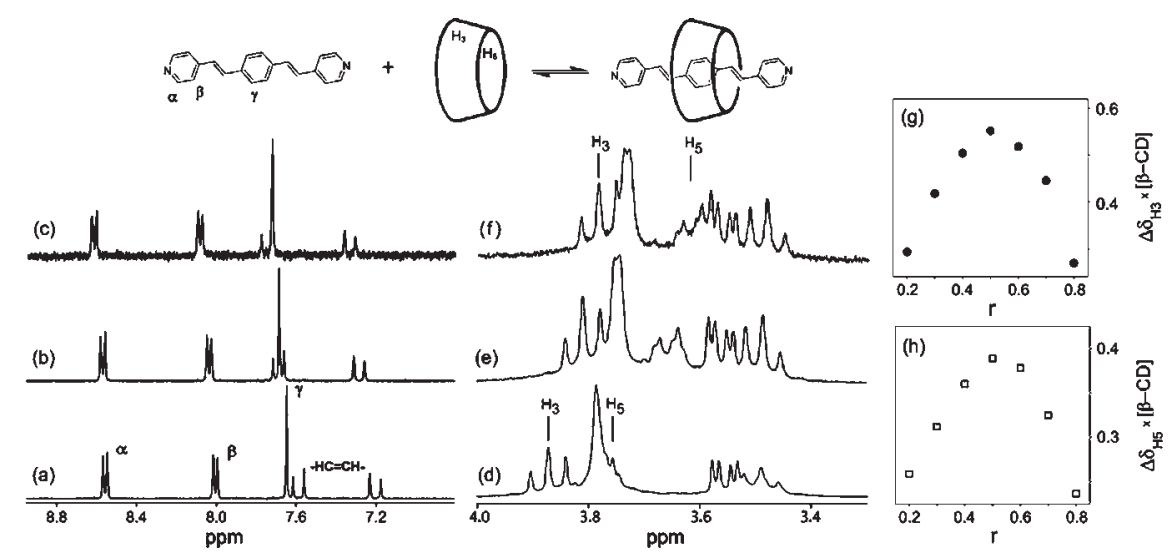

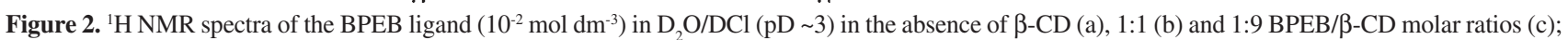
$\beta$-CD portion spectra in the absence of the BPEB guest (d), 1:1 (e) and 1:9 molar ratios (f). In the right, are shown the corresponding job plots of the $\beta$-CD/BPEB inclusion complex for the host inner protons $\mathrm{H} 3(\mathrm{~g})$ and $\mathrm{H} 5 \mathrm{(h}$ ). 

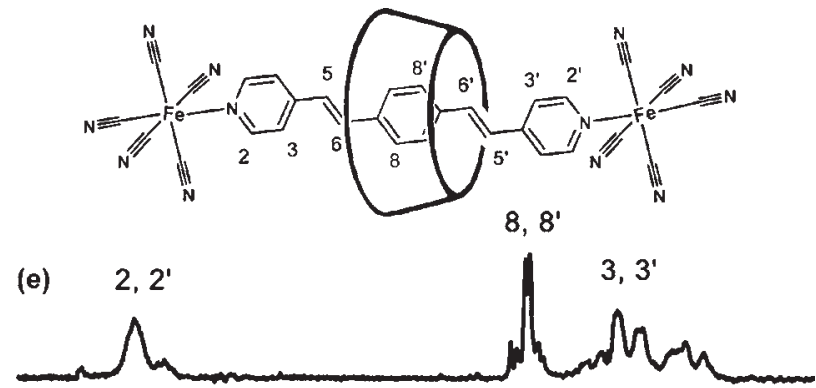

(d)

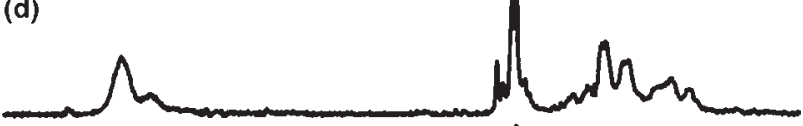

(c)

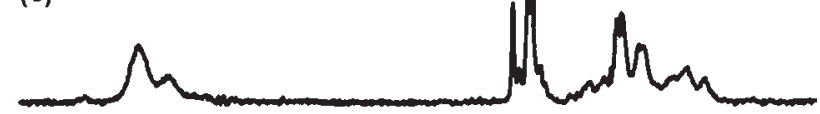

(b)

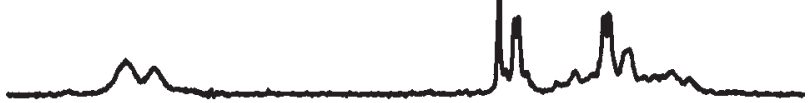

(a)

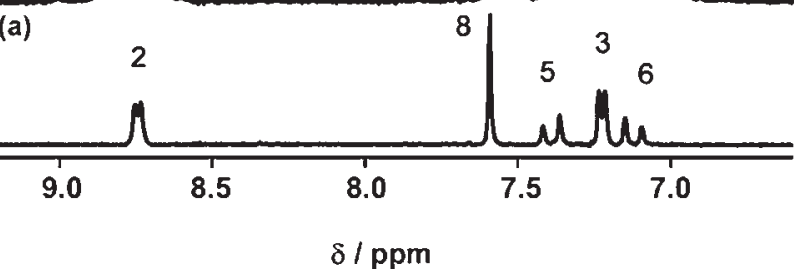

Figure 3. ${ }^{1} \mathrm{H}$ NMR spectra of the BPEB bridged ligand as function of time for the self-assembling $\left\{\left[\mathrm{Fe}\left(\mathrm{CN}_{5}\right)\right]_{2}\right.$ (BPEB. $\left.\left.\beta-\mathrm{CD}\right)\right\}^{6-}$ rotaxane, upon addition of 2 equivalents of $\beta$-CD to the dimer in $\mathrm{D}_{2} \mathrm{O}$ : (a) 0 min, (b) 5 min, (c) $30 \mathrm{~min}$, (d) $60 \mathrm{~min}$ and (e) 24 hours.

$\left.\times 10^{-5} \mathrm{~s}^{-1}\right)$ yielding the colorless $\left[\mathrm{Fe}(\mathrm{CN})_{5}(\mathrm{DMSO})\right]^{3-}$ species. ${ }^{25}$ Therefore, the inclusion process should be preceded by the dissociation of the $\left[\mathrm{Fe}(\mathrm{CN})_{5}\right]^{3-}$ group from the $\left\{\left[\mathrm{Fe}\left(\mathrm{CN}_{5}\right)\right]_{2}(\mathrm{BPEB})\right\}^{6-}$ complex, generating $\left\{\left[\mathrm{Fe}(\mathrm{CN})_{5}\right](\mathrm{BPEB})\right\}^{3-}$ intermediate species, which can undergo a fast equilibrium with $\beta-\mathrm{CD}$, yielding a pseudorotaxane, as illustrated in Scheme 1. The next step is a rapid recomplexation by the pentacyanoferrate(II) ending group yielding the rotaxane. A similar mechanism has also been proposed for the related bis(4-pyridine)ethylene complex. ${ }^{9}$

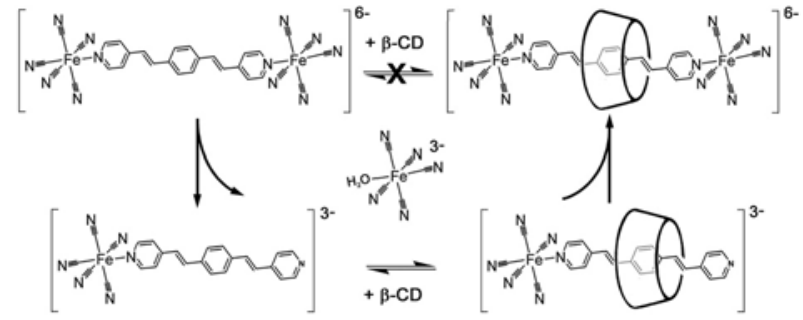

Scheme 1.

The electronic spectra of the $\left\{\left[\mathrm{Fe}(\mathrm{CN})_{5}\right]_{2}(\mathrm{BPEB})\right\}^{6-}$ and its included form with $\beta-\mathrm{CD}$ can be seen in Figure 4. The spectrum of the starting complexes is composed by two major bands at 352 and $454 \mathrm{~nm}$ ascribed to the intraligand (IL) $\pi \rightarrow \pi^{*}$ and the metal-to-ligand charge transfer (MLCT) $\mathrm{d} \pi \rightarrow \pi^{*}$ transitions, respectively. The inclusion of the BPEB bridging ligand results in the lowering of the MLCT band energy from 454 to $479 \mathrm{~nm}$. In $N$-heterocyclic pentacyanoferrates(II) complexes solvatochromic effects are well understood, exhibiting bathochromic shifts in the MLCT bands when less polar solvents are added to their aqueous solution. ${ }^{26,27}$ In these systems the nature of the $N$ heterocyclic ligand, i.e. hydrophobic strength, governs the extension of the solvatochromic shift, been greater as the

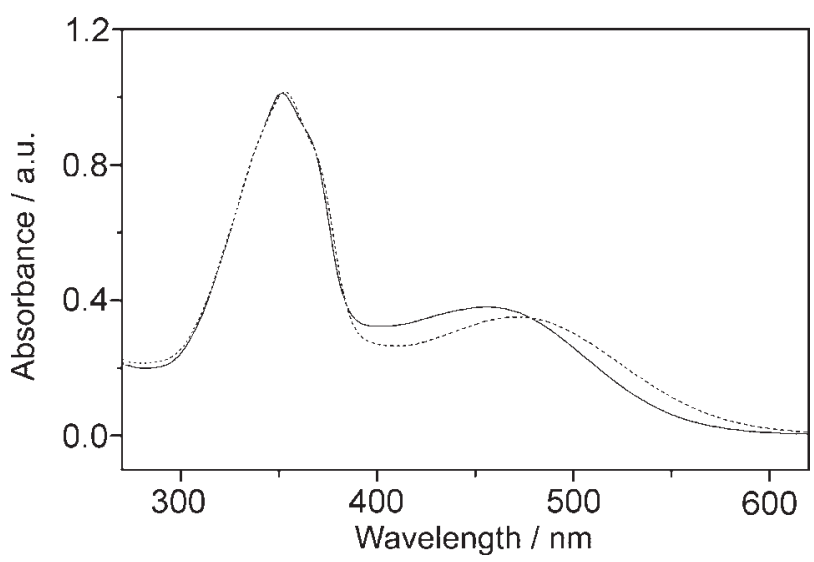

Figure 4. UV-Vis electronic spectra of the $\mathrm{Na}_{6}\left\{\left[\mathrm{Fe}(\mathrm{CN})_{5}\right]_{2} \mathrm{BPEB}\right\}(-)$ and the inclusion compound $\mathrm{Na}_{6}\left\{\left[\mathrm{Fe}(\mathrm{CN})_{5}\right]_{2} \mathrm{BPEB} . \beta-\mathrm{CD}\right\}(---)$.

Table 1. ${ }^{1} \mathrm{H}$ NMR chemical shifts for BPEB, BPEB $\beta \beta-\mathrm{CD},\left\{\left[\mathrm{Fe}(\mathrm{CN})_{5}\right]_{2}(\mathrm{BPEB})\right\}^{6-}$ and $\left\{\left[\mathrm{Fe}(\mathrm{CN})_{5}\right]_{2}(\mathrm{BPEB} \cdot \beta-\mathrm{CD})\right\}^{6-}$

\begin{tabular}{|c|c|c|c|c|}
\hline \multirow[t]{2}{*}{ Nucleus } & \multicolumn{4}{|c|}{ Chemical Shifts } \\
\hline & $\mathrm{BPEB}^{\mathrm{a}}$ & $\mathrm{BPEB} \cdot \beta-\mathrm{CD}^{\mathrm{a}, \mathrm{b}}$ & $\left\{\left[\mathrm{Fe}(\mathrm{CN})_{5}\right]_{2} \mathrm{BPEB}\right\}^{6-}$ & $\left\{\left[\mathrm{Fe}(\mathrm{CN})_{5}\right]_{2}(\mathrm{BPEB} \cdot \beta-\mathrm{CD})\right\}^{6-}$ \\
\hline $\mathrm{H}_{ \pm}$ & $8.558(\mathrm{~d})$ & $8.714(d)$ & $8.739(d)$ & 8.821 \\
\hline $\mathrm{H}_{2}$ & $8.005(\mathrm{~d})$ & $8.183(\mathrm{~d})$ & $7.220(\mathrm{~d})$ & $7.239 / 7.158$ \\
\hline $\mathrm{H}_{3}$ & $7.648(\mathrm{~s})$ & $7.822(\mathrm{~s})$ & $7.585(\mathrm{~s})$ & $7.539 / 7.527$ \\
\hline \multirow[t]{2}{*}{$-\mathrm{CH}=\mathrm{CH}-$} & $7.588(\mathrm{~d})$ & 7.849 (d) & $7.386(d)$ & $*$ \\
\hline & $\begin{array}{c}7.204(\mathrm{~d}) \\
\beta-\mathrm{CD}^{\mathrm{a}}\end{array}$ & $7.434(\mathrm{~d})$ & $7.112(\mathrm{~d})$ & $*$ \\
\hline $\mathrm{H}_{3}$ & $3.968(\mathrm{t})$ & $3.899(\mathrm{t})$ & - & $*$ \\
\hline $\mathrm{H}_{5}$ & $3.853(\mathrm{~m})$ & $3.713(\mathrm{~m})$ & - & $*$ \\
\hline
\end{tabular}

${ }^{\mathrm{a}}$ in $\mathrm{D}_{2} \mathrm{O} / \mathrm{DCl}$ solutions $\mathrm{pD}=2 ;{ }^{\mathrm{b}}$ from 1:9 mixture $\mathrm{BPEB} / \mathrm{\beta}-\mathrm{CD}$ solution; $*$ indeterminate. 
hydrophobicity increase. Likewise the solvent effects on the MLCT energies, the BPEB inclusion in the $\beta$-CD cavity results on the bathochomic shift related to preferential solvation of the ligand by the $\beta-C D$. This behavior could be associated to the stabilization of the energy levels of the $\beta-C D$ include ligand leading to a decrease of the MLCT energy.

The association constant for the rotaxane $\left\{\left[\mathrm{Fe}\left(\mathrm{CN}_{5}\right)\right]_{2}(\mathrm{BPEB} \cdot \beta-\mathrm{CD})\right\}^{6-}$ obtained by integration of the ${ }^{1} \mathrm{H}$ NMR peaks was $426 \pm 9 \mathrm{~mol}^{-1} \mathrm{dm}^{3}$ in comparison with $452 \mathrm{~mol}^{-1} \mathrm{dm}^{3}$ based on spectrophotometric measurements. This value is almost two times that previously reported for the related bis(4-pyridine)ethylene system $(\mathrm{K}=205$ $\left.\mathrm{mol}^{-1} \mathrm{dm}^{3}\right),{ }^{9}$ reflecting the increasing hydrophobic interactions promoted by the long chain BPEB ligand.

\section{Conclusions}

The trans-1,4-bis[2-(4-pyridyl)ethenyl]-benzene species forms $1: 1$ inclusion compounds with $\beta-C D$ in aqueous solution, proceeding according to a rapid dynamic process in the ${ }^{1} \mathrm{H}$ NMR time scale. The $\left[\left\{\mathrm{Fe}\left(\mathrm{CN}_{5}\right)\right\}_{2}(\mathrm{BPEB})\right]^{6-}$ complex forms a stable rotaxane species, but only very slowly. For this complex, the NMR experiments support a self-assembly mechanism involving the dissociation of the pentacyanoferrate(II) moiety, followed by the rapid inclusion of the Fe-coordinated BEPB ligand into the $\beta \mathrm{CD}$ ring, and by the binding of another $\left[\mathrm{Fe}(\mathrm{CN})_{5}\right]^{3-}$ complex, in order to generate the rotaxane species.

\section{Acknowledgments}

We gratefully thank the financial support from the Brazilian agencies CNPq, FAPESP, RENAMI and the $\mathrm{IM}^{2} \mathrm{C}$ Millenium Institute.

\section{References}

1. Toma, H. E.; An. Acad. Bras. Cienc. 2000, 72, 5.

2. Atwood, J. L.; Davies, J. E. D.; Macnicol, D. D.; Vögtle, F.; Comprehensive Supramolecular Chemistry, Szeijtli J.; Osa T., eds.; Pergamon/Elsevier: Oxford, 1996, vol. 3.
3. Dikavar, S.; Maheswaran, M. M.; J. Incl. Phenom. 1991, 27, 113.

4. Salvatierra, D.; Jaime, C.; Virjili A.; Sánchez-Ferrando F.; J. Org. Chem. 1996, 61, 9578.

5. Mirzoian, A.; Kaifer A. E.; Chem.-Eur. J. 1997, 3, 1052.

6. Loukas, Y. L.; J. Pharm. Pharmacol. 1997, 49, 944.

7. Oh, I; Lee, M.; Lee Y.; Shin, S.; Park, I.; Int. J. Pharm. 1998, $175,215$.

8. Djedaini, F.; Lin, S. Z.; Perly, B.; Wouessidjewe, D.; J. Pharm. Sci. 1990, 79, 643.

9. Baer, A. J.; Macartney, D. H.; Inorg. Chem. 2000, 39, 1410.

10. Wylie, R. S.; Macartney, D. H.; Inorg. Chem. 1993, 32, 1830.

11. Harada, A.; Acc. Chem. Res. 2001, 34, 456.

12. Nepogodiev, S. A.; Stoddart, J. F.; Chem. Rev. 1998, 98, 1959.

13. Haider, J. M.; Chavarot, M.; Weidner, S.; Sadler, I.; Williams, R. M.; De Cola, L.; Pikramenou, Z.; Inorg. Chem. 2001, 40, 3912.

14. Shukla, A.; Bajaja, H. C.; Das, A.; Angew.. Chem., Int. Ed. 2001, $40,446$.

15. Johnson, M. D.; Reinsborough V. C.; Ward, S.; Inorg. Chem. 1992, 31, 1085.

16. Toma, H. E.; Malin, J. M.; Inorg. Chem., 1973, 12, 1039.

17. Heck, R. F.; Organic Reactions 1981, 27, 345.

18. Amoroso, A. J.; Thompson, A. M. W. C.; Maher, J. P.; McCleverty, J. A.; Ward, M. D.; Inorg. Chem. 1995, 34, 4828.

19. Job, P.; Ann. Chim.. 1928, 9, 113.

20. Fielding, L.; Tetrahedron 2000, 56, 1615.

21. Scatchard G.; Ann N. Y. Acad.Sci. 1949, 51, 660.

22. Toma, S. H.; Uemi, M.; Nikolaou, S.; Tomazela, D. M.; Eberlin, M. N.; Toma, H. E.; Inorg. Chem. 2004, 43, 3521.

23. Malin, J. M.; Schmidt, C. F.; Toma, H. E.; Inorg. Chem. 1975, $14,2924$.

24. Toma, H. E.; Malin, J. M.; J. Am. Chem. Soc. 1975, 97, 288.

25. Toma, H. E.; Malin, J. M.; Inorg. Chem. 1973, 12, 2084.

26. Toma, H. E.; Takasugi, M. S.; Polyhedron 1989, 8, 941.

27. Burgess, J.; Spectrochim. Acta, Part A 1970, 26, 1957; Burgess, J.; ibid 1970, 26, 1369.

Received: March 3, 2006 Web Release Date: February 15, 2007

FAPESP helped in meeting the publication costs of this article. 